\title{
中耳炎耳におけるア之ノ配糖体薬剤
}

による内耳障害増強性

\author{
小針 仁 美
}

\section{Potentiation and its Mechanism of Cochlear Damage Resulting from Aminoglycoside Antibiotics Administration in Case of Experimental Otitis Media}

\author{
Hitomi Kobari \\ (Fukushima Medical College)
}

\begin{abstract}
Potentiation of the cochlear damage was studied after systemic administration of kanamycin (KM) in the case of experimentally induced otitis media.

Left eustachian tube was obstructed in guinea pigs to induce otitis media. Right ear was left intact as control. There were three types of histopathological changes after the eustachian tube obstruction, i.e., purulent otitis media, serous otitis media and a state that was considered to be healed condition.

The animals were given $400 \mathrm{mg} / \mathrm{kg}$ of $\mathrm{KM}$ at 2 days and 21 days following left eustachian tube obstruction for 10 consecutive days. Histopathological changes of outer hair cells at 10 days after the last KM administration were evaluated by the graphic cochlear reconstruction method using a light microscope. Concurrently, the histopathology was studied at 2, 3, 4 and 21 days following left eustachian tube obstruction as a control group. In the 21-day group of control animals, outer hair cell damage was observed at only the beginning portion of basal turn of cochlea of the left (experimental ear). In the KM administered group, the experimental result revealed significantly severer outer hair cell damage in all turn of cochlea in the left (experimental ear) than in the right (control ear).

The concentration of KM in perilymph was measured by bioassay at 4 hours and 24 hours after single administration of $400 \mathrm{mg} / \mathrm{kg}$ of $\mathrm{KM}$ and at 24 hours after the last administration of $400 \mathrm{mg} / \mathrm{kg} /$ day of $\mathrm{KM}$ for 10 consecutive days. There was no significant difference in the KM concentration in perilymph between experimental ear and control ear.

These results suggest that the increased cochlear damage after $\mathrm{KM}$ administration during otitis media was not due to the increase of KM level in the inner ear, and also suggest that two different kinds of ototoxic agents which are aminoglycoside antibiotics and otitis media can cause severer cochlear damage than the sum of each damage.
\end{abstract}

Key words: potentiation, cochlear damage, otitis media, aminoglycoside antibiotics 
はじめに

アミノ配糖体薬剂は，難治な感染症の治療に 大きく役立っている一方で, 副作用として聴器 毒性，腎毒性を有することが古くから知られて いる。この聴器毒性に関しては，現在に至るま で膨大な基礎的，実験的な研究がなされ，これ らの薬剤による内耳障害の様式や機序について 非常に多くのことが解明され，日常臨床に扔い てあその使用にあたっては充分な注意が払われ るようになってきている.

しかし，これらの聴器毒性についての実験的 研究は, 現在まで主として正常耳においてなさ れており，最む一般的な病的状態である中耳炎 耳においてとれらの薬剤が使用された場合に， 正常耳と異なり，内耳障害がどの様に変化する かは未だ充分に明確にされていない，しかむ中 耳炎の経過が遷延するに従い，グラム陰性桿菌 感染が増加し，アミノ配糖体薬剂を使用する機 会も多くなるととが予想されるため，中耳炎耳 に扔いて耳毒性薬剤が使用された場合の内耳障 害の評価を正確に行うことが，臨床上からも重
要である．今回著者は，中耳炎耳においてアミ ノ配糖体薬剂を全身的に投与した際に引き起こ される内耳障害が，正常耳の場合とどの様に異 なるかを実験的に検討した。すなわち，動物に 中耳炎を作成し，アミノ配糖体薬剂を全身投与 して，正常耳之中耳炎耳の内耳障害について比 較検討を行った。ささらに，中耳炎耳と正常耳に ついての薬剤の内耳移行に差があるかどうかを 検討した。これらの実験結果から興味ある知見 が得られたので報告する.

\section{実験方法}

実験動物として，プライエル反射正常，針状 硬性鏡下に鼓膜正常で体重 $200 \sim 350 \mathrm{~g}$ のハー トレー系雄性モルモット52匹を使用した。この うち病理組織学的検索に33匹を，薬剤の内耳移 行についての検索に19匹を使用した.

実験的中耳炎の作成は次の方法によって行っ た.nembutal (pentobarbital sodium $50 \mathrm{mg} / \mathrm{ml}$ ) 腹腔内注射により麻酔を行った後，動物を仰卧 位とし，開口して軟口蓋正中切開を入れた。. 左 右の耳管咽頭口を明視下におき，左側の耳管咽

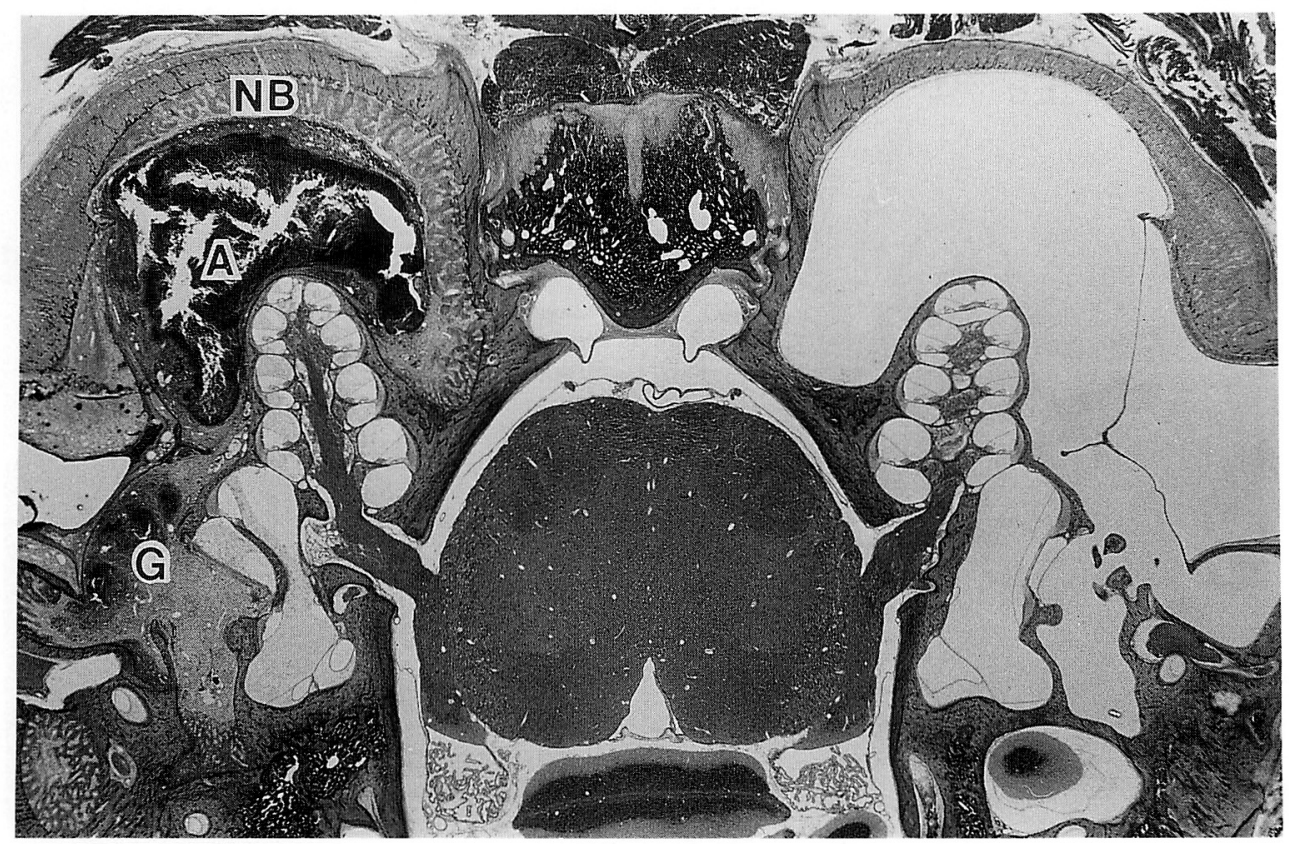

図1 左耳管咽頭口閉鎖後の中耳腔の病理組織学的変化. 左中耳腔に膿瘍 $(A)$, 肉芽形成 $(G)$ を認め，粘膜下結合組織内には炎症細胞浸潤と骨新生 (NB) を認める化膿性中耳炎. 


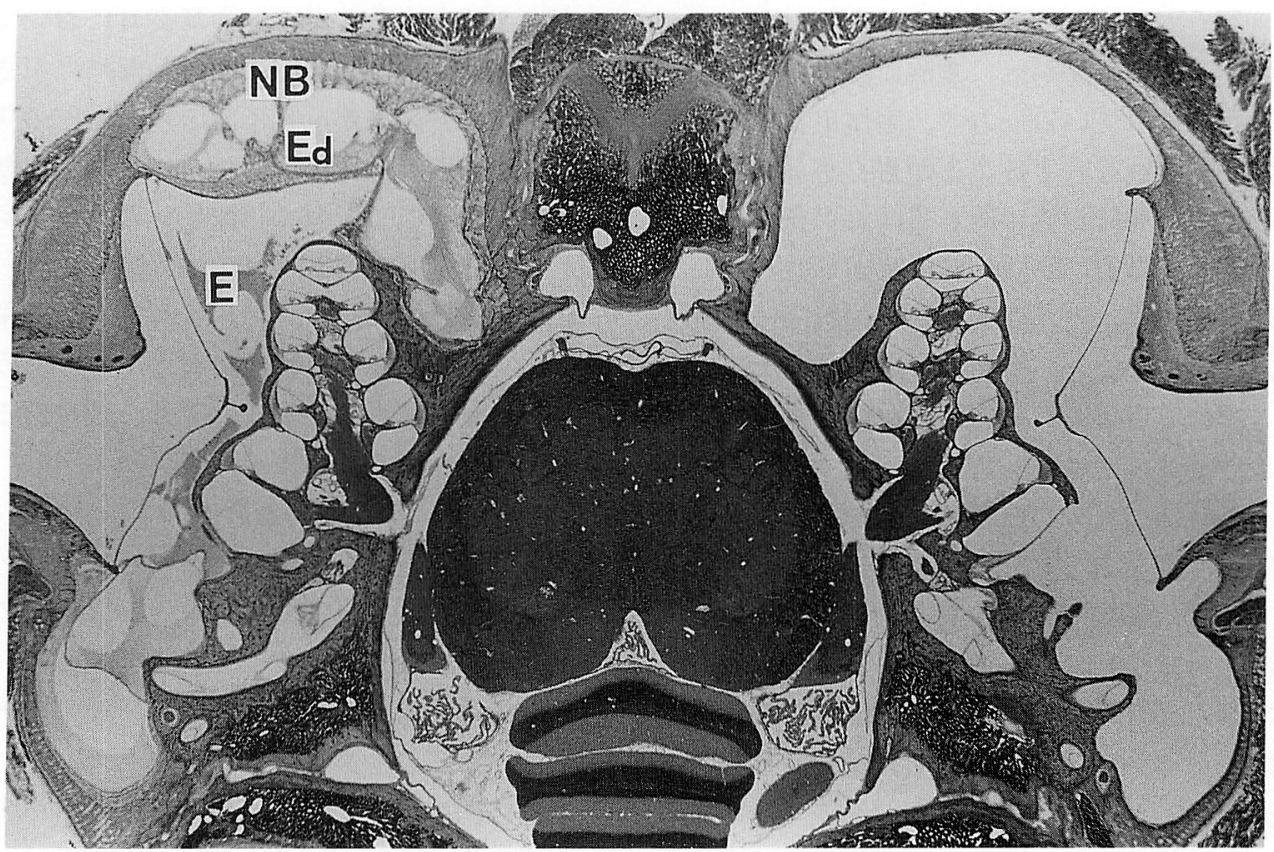

図 2 左耳管咽頭口閉銷後の中耳腔の病理組織学的変化. 左中耳腔内には, 少数の炎症細胞浸 潤を伴ってェオジンに淡染する眝留液 (E) を認め, 粘膜下結合組織内には著明な浮腫 (Ed) と新骨生 $(\mathrm{NB})$ を認める非化膿性漿液性中耳炎.

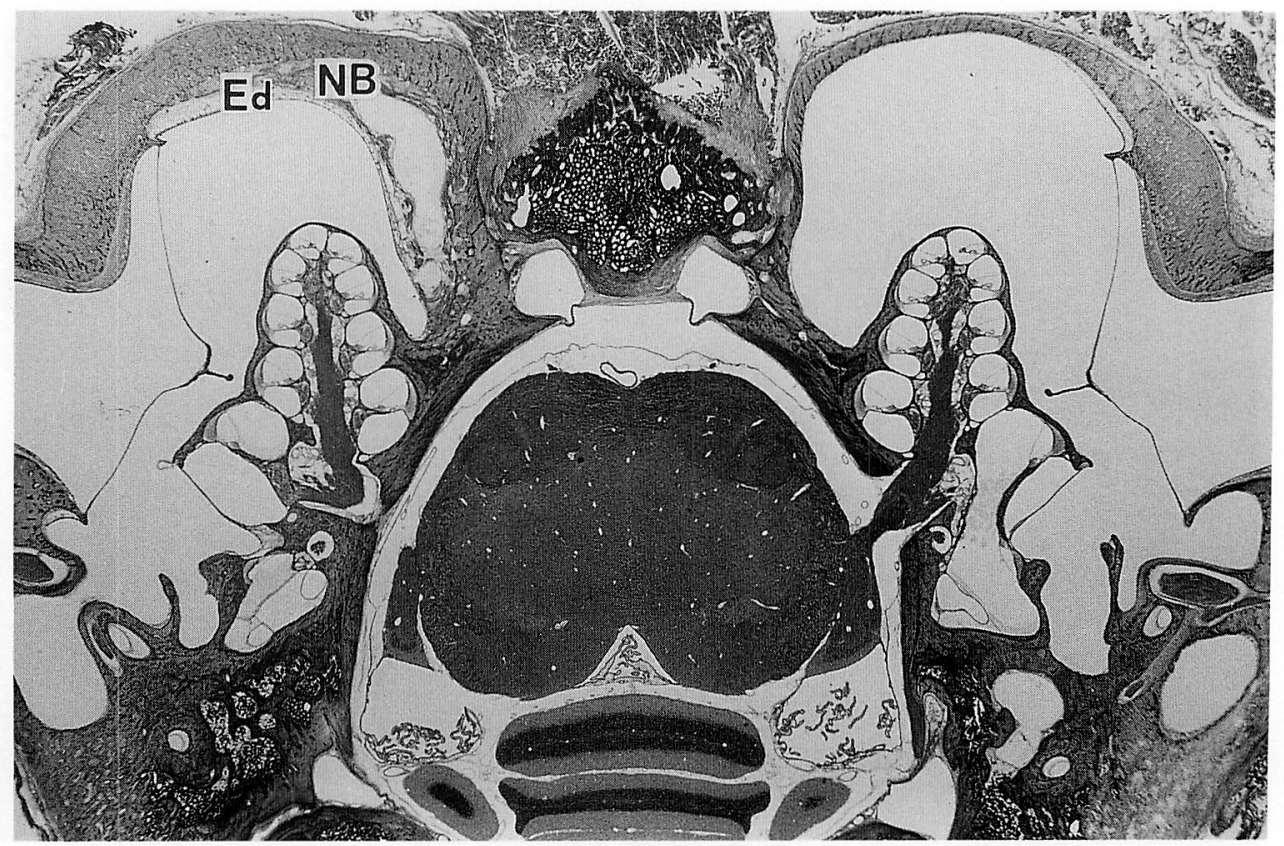

図 3 左耳管咽頭口閉銷後の中耳腔の病理組織学的変化.中耳腔内には眝留液は存在せず，粘 膜下結合組織内に浮腫 $(\mathrm{Ed})$ と骨新生 $(\mathrm{NB})$ を認める. 
頭ロにシリコンの小片を 1 〜 ケ插入して耳管 を充填し，さらに電気焼灼を行って耳管を閉塞 せしめた。軟口蓋の切離面は縫合した。右側は 操作を加えずコントロールとした。

使用した薬剂は kanamycin (KM) で，生理
食塩水で $100 \mathrm{mg} / \mathrm{ml}$ に溶解して使用し，投与 方法はすべて筋肉内注射とした。

1. 実験的中耳炎におけるアミノ配糖体薬剂 の耳毒性について一病理組織学的検索

前述の方法により作成した実験的中耳炎モル
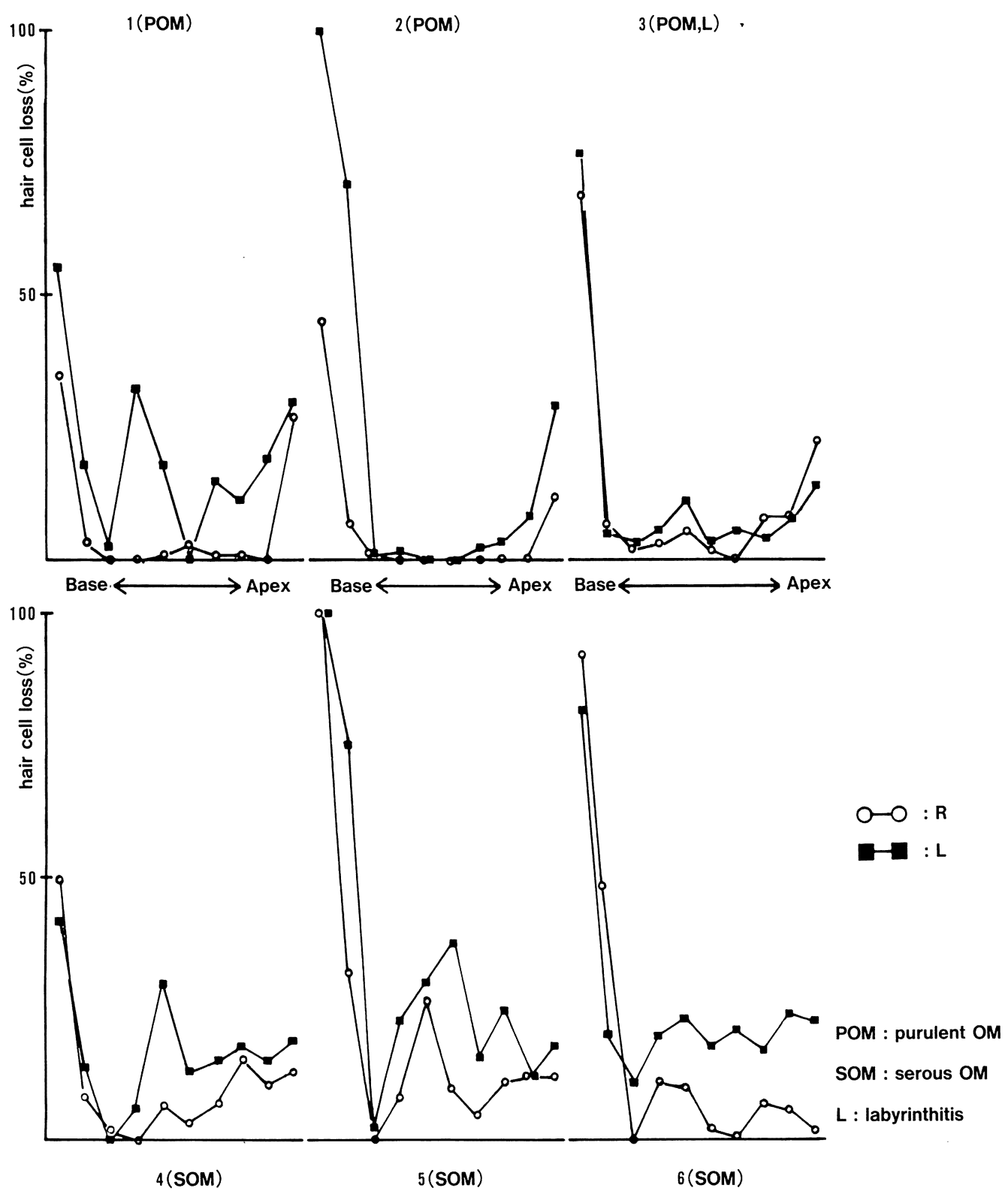

図 4 耳管咽頭口閉鎖 2 日後から KM 投与を行った群（第 1 群）における外有毛細胞障害. 左側 (中耳炎側) で障害が高度である。 
モット33匹を次の 3 群に分けて使用した. 第 1 群（9匹）; 中耳炎作成手術 2 日目より $\mathrm{KM}$ $400 \mathrm{mg} / \mathrm{kg}$ を連続 10 日間筋注した後, 10 日目 に断頭. 第 2 群(15匹); 手術21日目より $\mathrm{KM}$ $400 \mathrm{mg} / \mathrm{kg}$ を連続 10 日間筋注した後, 10 日目 に断頭. 第 3 群（コントロール群）（9匹）; 手 術 2 日，3日，4 日，21日目に断頭.

今回の実験では，同一個体で左右の中耳と内 耳を同一面で観察する目的で光学顕微鏡的観察 を行った.動物は以上の 3 群について, nembutal 麻酔下に Heidenhain SuSa 液にて生体灌流固 定を行って側頭骨を採取し、さらに同固定液で 48時間後固定を行った. その後常法に従って脱 灰, 脱水し, ツエロイジン包埋を行い, $25 \mu$ に 薄切後, 2 枚毎に H-E 染色を施し観察した.

蝸牛を Graphic cochlear reconstruction 法 ${ }^{122)}$ 用いて再構築した後その全長を10分割し，各々 の区域内の障害された有毛細胞の数を百分率で 表した。有毛細胞の障害は核の消失をもって障 害ありとした。

2. 実験的中耳炎における薬剤の内耳移行に ついての検索一外リンパ中薬剂濃度の測定

動物を次の 2 群に分けて使用した。(1)，1回 投与群 (15匹) ; 前述の方法で左側の実験的中耳 炎を作成48時間後に KM $400 \mathrm{mg} / \mathrm{kg}$ を筋注 し，その後 4 時間，24時間後に断頭し，左右の 内耳液（前庭階および鼓室階外リンパ）を採取 した. (2)，連続投与群 ( 4 匹) ; 左側の実験的中 耳炎作成48時間後より KM $400 \mathrm{mg} / \mathrm{kg}$ を連続 10 日間筋注し，最終投与の 24 時間後に断頭して 左右の内耳液（前庭階および鼓室階外リンパ） を採取した。、いずれの群も内耳液の採取は Ohtani ら ${ }^{3)}$ の報告に従って行い，中耳炎耳の場 合には両空部の貯留液をろ紙にて慎重に除去し たのちに行った。内耳液の薬剤濃度の測定は， Bacillus subtilis ATCC 6633 を検定菌とする Bioassay 法3)により行った. 外リンパ中の薬剤 濃度は前庭階, 鼓室階の值を平均した。

\section{実験結果}

1. 実験的中耳炎におけるアミノ配糖体薬剤
による内耳障害について

1）中耳の病理組織学的変化について

耳管咽頭口閉鎖による中耳腔の病理組織学的 変化は次の 3 つに分類された. (1)，中耳腔に好 中球を中心とする夥しい炎症細胞浸潤を伴った 貯留液, 肉芽形成, 膿瘍が存在し, 中耳粘膜は 肥厚し，粘膜下結合組織内には著明な骨新生と 共に多核白血球，形質細胞を中心とする炎症細 胞浸潤を認める化膿性炎症（図 1)。(2)，中耳 腔内にマクロファージやリンパ球などの少数の 炎症細胞浸潤を伴って，エオジンに淡染する貯 留液を認め, 粘膜下の結合組織の浮腫性変化之 骨新生を認める非化膿性嶈液性炎症（図 2).

(3)，中耳腔に貯留液は存在せず，粘膜下結合組 織に浮腫と骨新生を認め，炎症の治癒した状態 と考えられるもの（因 3 ).

第 1 群では 9 匹中 2 匹に両側中耳炎が認めら れたため，ての 2 匹を検討例から除外した. 残 る 7 匹中，3匹に左化膿性中耳炎，3匹に左漿 液性中耳炎が認められた。1 匹では中耳貯留液 を認めず，粘膜下結合組織の浮腫性変化を認め るのみであった．右側では中耳腔に貯留液を認 めず，粘膜下結合組織には軽度の浮腫を認める

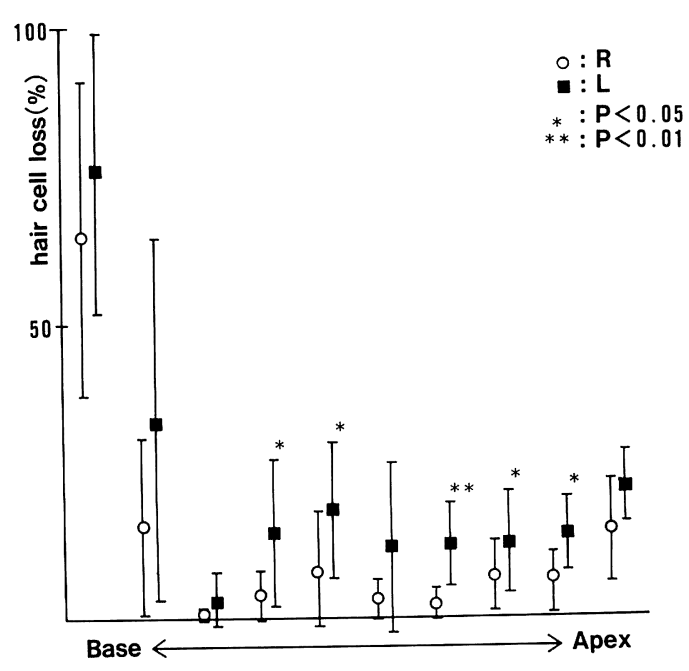

図 5 耳管咽頭口開鎖 2 日後から KM 投与を行った 群 (第 1 群) におりる外有毛細胞障害. 中耳炎 側（左）においてコントロール側（右）よりも 高度な障害を認める。 
あの屯あったが，炎症細胞浸潤はみられなかっ た. 第 2 群では15匹中 3 匹に両側中耳炎, 1 匹 に左側の重篤な内耳炎を認めたためての 4 匹を 除外した. $11 匹 中 4$ 匹に左化膿性中耳炎， 4 匹 に左漿液性中耳炎を認め，3 匹に貯留液を認め なかった．右側では11匹全例に中耳貯留液を認 めず，正常ないし粘膜下結合組織に中等度の浮 腫と，同部位に形質細胞などの炎症細胞浸潤が 認められるものがあった。第 3 群（コントロー ル群）では，手術 2 日目から左側中耳腔の粘膜 下結合組織に浮腫と毛細血管の拡張を認めると
ともに中耳腔に貯留液が出現した。術後21日目 では全例に左化膿性中耳炎が認められた。

2）有毛細胞の障害について

(1) 内有毛細胞障害

内有毛細胞の障害は第 1 群 ( 7 匹) とコント ロール群である第 3 群（9匹）では認められな かった．第 2 群で11匹中 2 匹に内有毛細胞障害 が認められ，それぞれ左化膿性中耳炎と中耳炎 の治㾍後のもので，前者は障害は左側の第 3 回 転から頂回転にかけて認められ，後者では障害 は左右同程度で部位は第 3 回転から頂回転にか

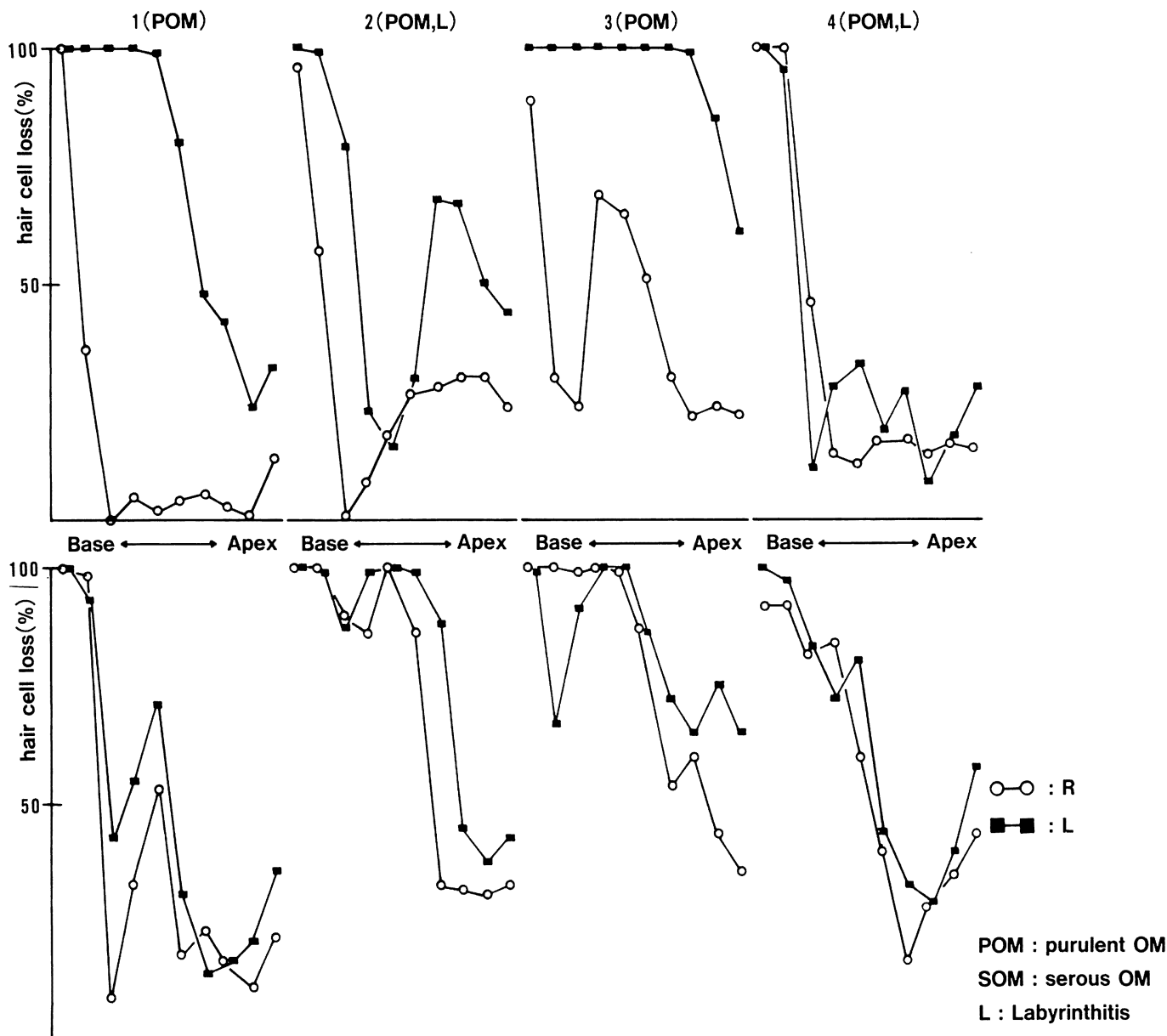

5 (SOM)

6 (SOM)

7 (SOM)

8 (SOM)

図 6 耳管咽頭口閉鎖21日後加ら KM 投与を行った群（第 2 群）におりる外有毛細胞障害. 左側（中耳炎側）で障害が高度である. 
けてであった。

(2) 外有毛細胞障害

第 1 群; 検討した 7 匹全例に外有毛細胞障害 が認められた。中耳貯留液を認めなかった 1 匹

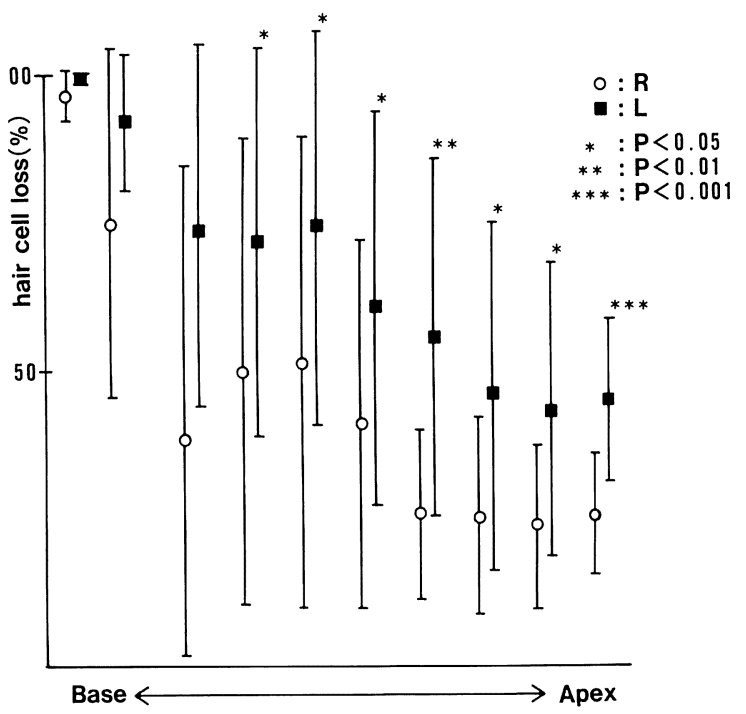

図 7 耳管咽頭口閧鎖 21 日後から KM 投与を行った 群（第 2 群）におりる外有毛細胞障害. 中耳炎側（左）においてコントロール側（右） よりも高度な障害を認める。
を除き，左側中耳炎が認められた 6 匹ではほぼ 全例で左側（実験側）において右側（コントロ ール側)よりあ高度な障害が認められた(図 4). これら 6 匹の結果をまとめると図 5 の如くであ り，全回転にわたって左側（実験側）において 障害が強いととが明らかであり，部位によって は障害の強さに統計学的な有意差が認められ た. 中耳炎の治療後の 1 匹ではやや左側（実験 側）において障害が強い傾向であった（図 8).

第 2 群；11匹中左側の中耳炎が認められた 8 匹では，全例に外有毛細胞障害が認められ，そ の範囲は基底回転に留まるものから頂回転に至 るあのまで個体差が認められたが，全体的に障 害は 1 群より高度であった(図 6). 右側（コン トロール側）においてあ 1 群よりあ高度な障害 が認められ, 中耳粘膜の病理組織学的変化の大 きいむのに障害が強い傾向がみられた８ 8 匹の 障害をまとめると図 7 の如くであり，基底回転 起始部では左右同程度の障害であるが，より上 方では頂回転に至るまで左側において高度な障 害が認められ，部位によっては統計学的な有意 差が認められた。中耳炎の治瘱後の 3 匹では左

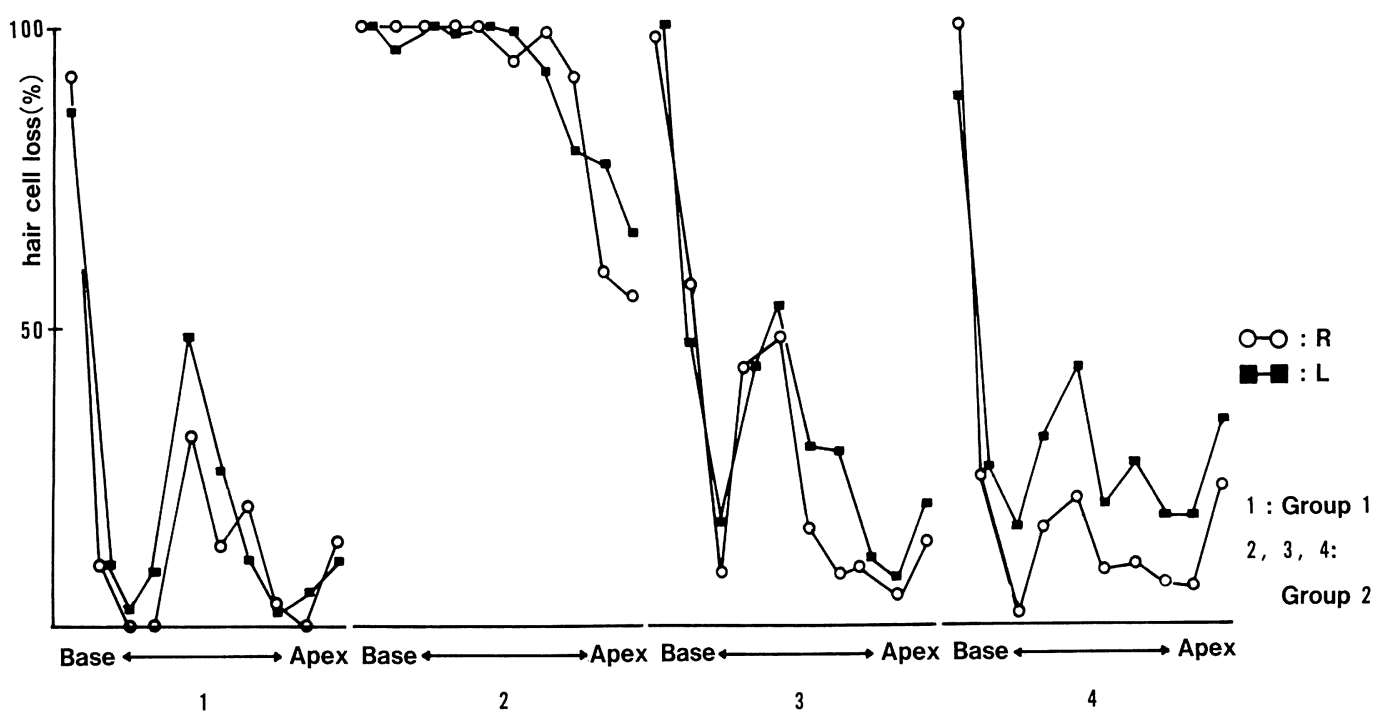

図 8 断頭時に中耳貯留液を認めなかった例における外有毛細胞障害 ( 1 ; 第 1 群, $2,3,4$; 第 2 群).

左 (中耳炎側) で障害が強い傾向である. 


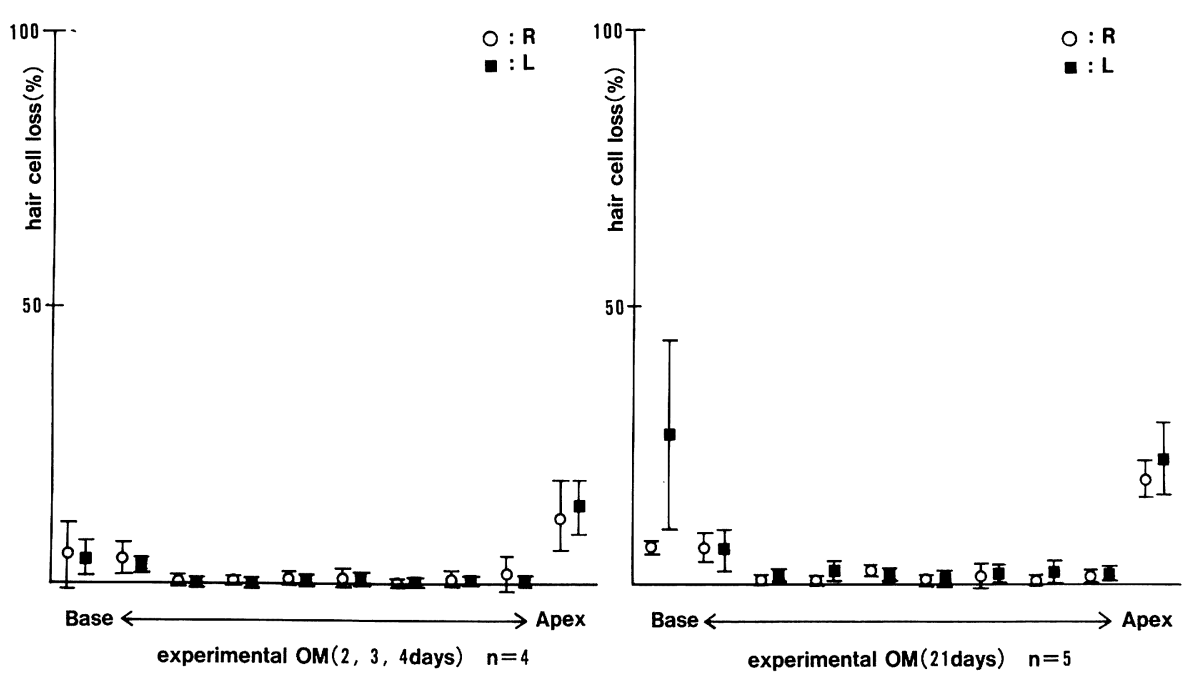

図 9 コントロール群（第 3 群）におりる外有毛細胞障害. 21日群において 中耳炎側（左）の基底回転起始部に障害を認める.

表 1 実験的中耳炎 (左側)における KM 投与後の外リンパ中濃度 $(\mu \mathrm{g} / \mathrm{ml})$

\begin{tabular}{|c|c|c|c|}
\hline & \multicolumn{2}{|c|}{ 一回 投 与 群 } & \multirow{2}{*}{ 連続投与群 } \\
\hline & 4 時 間 & 24 時 間 & \\
\hline 右 （コントロール側） & $33.88 \pm 10.25$ (8) & $2.91 \pm 1.27$ & $11.63 \pm 3.92(4)$ \\
\hline 左 (中耳炎 側) & $33.26 \pm 7.54$ (8) & $3.61 \pm 1.52(7)$ & $10.25 \pm 4.19$ (4) \\
\hline
\end{tabular}

数值は mean $\pm \mathrm{SD}$ （）内は動物数を示す. $\mathrm{t}$ 検定で左右間に有意差を認めない.

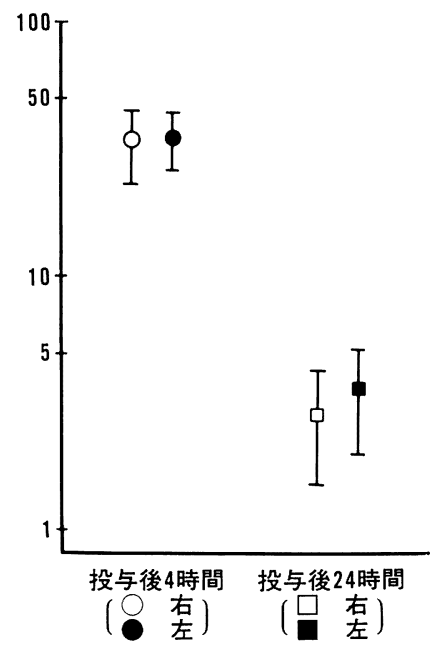

図10 KM $400 \mathrm{mg} / \mathrm{kg} 1$ 回投与後 4 時間，24時間の 外リンパ中濃度 $(\mu \mathrm{g} / \mathrm{ml})$. 4 時間, 24 時間とも に中耳炎側とコントロール側との間に有意差を 認めない.

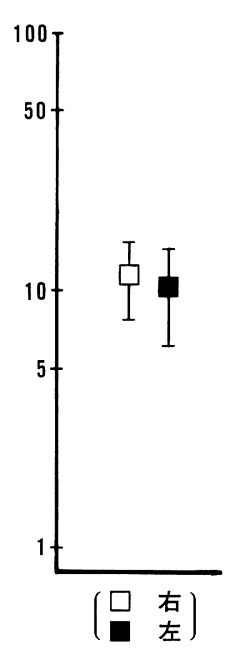

図11 KM 連続投与後 24 時間の外リンパ中濃度 $(\mu \mathrm{g} / \mathrm{ml})$. 中耳炎側とコントロール側で有 意差を認めない。 
側に障害が強い傾向であった（図 8).

第 3 群; 手術後 2，3，4 日目迄の動物では， 左右ともに外有毛細胞に障害を認めなかった。 手術後21日では基底回転起始部において左側に 有意な障害が認められた（図 9）.

\section{2. 薬剤の内耳移行について}

1 回投与群 (15匹); 断頭時全例に左中耳腔内 に貯留液を認めた。 $\mathrm{KM} 400 \mathrm{mg} / \mathrm{kg}$ 筋注後 4 時間， 24 時間の外リンパ中の $\mathrm{KM}$ 濃度を表 1 , 図10に示した。投与後24時間で左側（実験側） 外リンパ中の $\mathrm{KM}$ 濃度が右側（コントロール 側）に比較して高い傾向がみられたが，統計学 的な有意差は認められなかった。

連続投与群 ( 4 匹) ; 断頭時全例に左中耳腔内 に貯留液を認めた。外リンパ中の $\mathrm{KM}$ 濃度を 表 1, 図11に示した. 正常耳と中耳炎耳におい て外リンパ中の $\mathrm{KM}$ 濃度に差を認めなかった。

\section{考察}

今回の実験から，実験的中耳炎動物にアミノ 配糖体薬剂である kanamycin (KM) を全身投 与した結果，正常耳においてよりあ中耳炎耳に おいて高度の外有毛細胞障害が認められた。し かし一方, 薬剂投与後の内耳液中濃度には, 中 耳炎耳と正常耳との間に有意差はみられなかっ た. 以下，乙の結果について考察を加える.

1. 耳管咽頭口閉鎖によって引き起てされた 中耳の病理組織学的変化

今回モルモットの耳管咽頭口閉鎖によって, 閉鎖 2 日後から左中耳粘膜下結合織内の浮腫之 中耳腔内に貯留液の出現をみた。さらに断頭時 には中耳腔の病理組織学的変化は前述の如く化 膿性中耳炎, 非化膿性墏液性中耳炎, 眝留液を認 めないものの 3 つに分けられた。 これらのうち 貯留液を認めなかった群については, 粘膜下結 合組内に浮腫や骨新生などが認められたととか ら，一度は中耳炎が惹起されたが恐らく耳管の 再開通により炎症の終息をみた状態と考えられ た。

動物における実験的中耳炎モデルの作成の手 段として, 耳管に何らかの操作を加え, 器質
的，機能的な閉塞状態を作りだす実験が種々 行われている，すなわち，耳管を結染する方 法45)，耳管咽頭口或は鼓室口を電気または薬

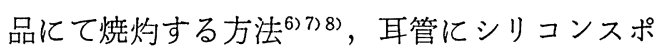
ンジなどを充填する方法91011112) などがあり， いずれの方法でも完全に閉塞すれば中耳腔に液 体が貯留するといわれている113)。 またその他 に，耳管咽頭口に電子線を照射し，機能的閉塞 状態を作りだして中耳炎の作成を行ったという 報告あある(4)15)。今回モルモットにおいて惹起 された中耳炎は化膿性中耳炎と，いわゆる臨床 的には滲出性中耳炎と同様と考えられる非化膿 性漿液性中耳炎であり， mucoid type のあのは 観察されなかった。乙れらの中耳炎は，耳管咽 頭口閉塞後に滲出性中耳炎の状態となり感染を 合併しないままに経過したか，またはまず滲出 性中耳炎の状態となり感染を合併したのか， あ るいは早期に感染し，投与された KM によっ て化膿性炎症が終息したものか不明である。耳 管咽頭口を処置することにより膿性の眝留液の 出現を見ることが多いことは真崎 ${ }^{16)}$ む指摘して いるところであるが，滲出性中耳炎むその発症 に感染の関与が重要視されており, 軽度の中耳 腔の炎症状態であるということで，乙れら惹起 された中耳炎について一括して内耳障害につい て検討を行った。 また右耳については，断頭時 には全例に眝留液を認めず，2 日群ではほぼ正 常の所見を呈していたが，21日群では粘膜下結 合組織の浮腫やごく軽度の炎症細胞浸潤が認め られるあのがあり，乙れらは手術侵襲により上 咽頭，耳管を経由して右側にも一過性に中耳炎 が起とったものと推測された。

2. 外有毛細胞障害について

1）コントロール群

コントロール群においては，耳管閉塞後 2 4 日目までの群では外有毛細胞の障害は認めら れなかったが，21日群では左側の基底回転起始 部に限局した障害が認められた。これらの動物 では全例に左側の化膿性中耳炎が起こっており， 障害は中耳炎の内耳への波及によるためと考え 
られた。

一般に慢性中耳炎において骨導聴力の低下が みられることが，臨床的に以前より明らかにさ れており 17) 18) 19)20)，中耳腔内の炎症病変が内耳 にどの様な影響を与えるかについての検索が行 われている，すなわち，Walby ら ${ }^{21)}$ は慢性中 耳炎の側頭骨の検索で有毛細胞や蝸牛神経成分 に異常を認めず，骨導聴力の低下は音の伝達経 路に何らかの変化が起てるためであろうと推測 している. しかし，中井22233 はヒト中耳炎の側 頭骨を検索し，前庭空，蝸牛空の肉芽病変と細 胞浸潤, 及び鼓室階外リンパに漿液性沈殿物を 認め, 中耳から内耳への炎症の波及は主として 正円空膜を介してなされることを報告し，さら に動物を用いての観察ではラセン器は鼓室階よ りの炎症反応物質や細胞浸潤によって障害され ることを述べている。 また Paparella ら ${ }^{2425)}$ 鼓室に炎症のある場合, 蝸牛空付近に toxin に よる限局性迷路炎を起てしていることを明らか にしている。また Hodges ら ${ }^{26)}$ は細菌注入によ り実験的中耳炎を作成し内耳の变化を電顕的に 観察したが，支持細胞の障害，有毛細胞の stereocilia の変化，ついには有毛細胞の変性消失 に至る一連の変化がみられたてとを報告してい る.さらに急性中耳炎の動物モデルであ，内耳 液蛋白の $\gamma$-グロブリンの増加を認め，漿液性 内耳炎が惹起される可能性があるととあ示唆さ れている ${ }^{27)}$. 以上のように中耳腔の炎症が内耳 有毛細胞に障害を与えるととが，過去の報告か らあ明らかである。

2) kanamycin 投与群一中耳炎耳での内耳 障害増強性の原因について一

2 日群，21日群共に全動物に外有毛細胞障害 が認められ，その障害はコントロール側(右側) に比較して中耳炎側（左側）で高度であり，ま た2 日群に比べて21日群でより大きい傾向が認 められた。

過去に打いて Federspil ${ }^{28)}$ は，中耳炎を有す るモルモットに tobramycin と gentamicin を投 与し, 生化学的, 及び病理組織学的に検索を行
った。それによると，中耳炎耳においては外リ ンパ中の薬剤濃度が高まり，乙れらの薬剂の耳 毒性が有意に強まっており，乙の原因は中耳貯 留液と外リンパ間の薬剂移行及び血管透過性の 穴進によるためであろうと考察を加えている. 一般に副作用屯含めて薬剂の薬理効果 $\mathrm{E}$ は, 薬

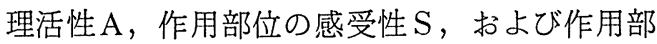
位での薬剤濃度 $\mathrm{C} に よ っ て$ 規定され， $\mathrm{E}=\mathrm{kf}$ $(\mathrm{A}, \mathrm{S}, \mathrm{C})$ と表される ${ }^{299}$. 中耳炎耳に抢ける内 耳障害の增強性が内耳における濃度の増加によ るものか, 有毛細胞の感受性の変化によるもの か考えてみたい.

全身投与されたアミノ配糖体薬剂の内耳有毛 細胞への到達経路としては, (1)蝸牛血管叢 $\rightarrow$ 神

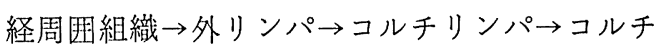
器 ${ }^{30}$ 31) 32) 33)，(2)血管条 $\rightarrow$ 内リンパ $\rightarrow$ 有毛細 胞 ${ }^{34)}$ ，(3)ラセン血管 $\rightarrow$ 有毛細胞 ${ }^{35)}$ ，(4)脳脊䯣液 $\rightarrow$ 外リンパ $\rightarrow$ 有毛細胞 ${ }^{36)}$ ，(5)蝸牛空 $\rightarrow$ 外リンパ

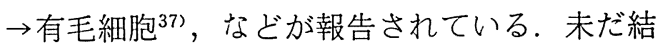
論は得られていないがこれらの到達経路のうち (1)のルートが主たるあのと考えられている. 今 回の実験でも筋注された KM は主として神経 周囲組織から外リンパ，コルチリンパと移行 し，有毛細胞に到達したと考えられるが，今回 の実験では中耳炎という正常時とは異なる異常 な環境にあったわけである。すなわち炎症は一 般的に炎症性循環障害, 炎症性滲出, そして修 復の諸過程から成り立ち，まず一過性の血管修 復, 細動脈の拡張, 毛細血管および細静脈の拡 張などの即時的な血管反応に始まり，血管透過 性の亢進を来す。乙れにより血清，血漿成分の 滲出, また炎症細胞の遊出, 浸潤を来す 38 ). 乙 れら一連の変化は当然中耳あるいは内耳でも起 こっているむのと予想され，血管透過性の元進 により薬剤の吸収が盛んになり， $\mathrm{KM}$ の内耳 有毛細胞への移行が大となる可能性 ${ }^{39}$ ああると 考えられる。

またさらに考えられる内耳への薬剤の到達経 路として, 中耳貯留液から外リンパへの経路が あげられる.富山ら ${ }^{40)}$ は全身投与された抗生物 
質が滲出性中耳炎の中耳貯留液中に移行するこ とを明らかにしている。またその他にも経口剂 の中耳貯留液中への移行について報告が行われ ている ${ }^{41) 422}$. 鼓室内に注入された薬剤が有毛細 胞障害を引き起とす事は, Schuknecht ${ }^{43)}$, Koide $\zeta^{44)}$ ，豊田 ${ }^{45)}$ ， 中井 ${ }^{46)}$ ，Brummett

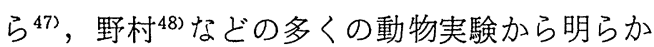
になっており，また臨床的にも点耳薬性難聴と して耳毒性薬剤の点耳にあたっては注意が促さ れている ${ }^{39949)}$. 中耳腔から内耳への薬剤の侵入 経路は，主として正円空膜を介してと考えられ ている23339949．すなわち正円空膜の様々な物質 の透過性に関しての実験が行われ, cefmetazole sodium $^{48)}$, steroid ${ }^{48)}$, Na イオン ${ }^{50)}$, gentami$\mathrm{cin}^{51)}$, neomycin ${ }^{51) 52)}$ などの物質を容易に通過 させることが確かめられている．さらに正常状 態では ferritin, albmin など分子量の大きいも のは通過させないととが明らかになっている48).

しかし実験的中耳炎耳に打いては，野村 ${ }^{48)}$ は 正円空膜が ferritin を通過させることを報告し ており，また Goycoolea ら ${ }^{53)} は$ 猫に実験的中耳 炎を作成し，正円空膜の透過性を albmin を用 いて検索したところ，正常耳に比して透過性の 六進を認めている。ささらに野村は, 滲出性中耳 炎の場合には中耳粘膜に上皮の脱落変性, 基底 板の障害などがあるため鼓室内の薬剤は正常 耳に扔いてよりあ内耳に移行し易い状態にある と説明している ${ }^{39949)}$. 以上のように特に病的状 態においては，中耳腔に存在する耳毒性薬剤は 正常耳においてより屯有毛細胞障害を起こし易 いことが考えられる. しかし一方, Sahni ら54 は側頭骨標本の検索で，慢性中耳炎患者では急 性中耳炎，漿液性中耳炎に比較して，正円空膜 が肥厚しており，内耳の防御に役立っていると 考察を加え，また Schachern ら ${ }^{55)}$ は実験的中 耳炎では正円空膜の HRP 透過性が減少してい ることを報告している．乙のように中耳炎耳に おける正円空膜の透過性については未だ充分明 らかにされておらず，従って中耳炎耳の中耳貯 留液中から外リンパへの KM の移行について
は更に検討を要するものと思われる.

今回の著者の実験においては，薬剤の 1 回投 与後も連続投与後も, 外リンパ中の $\mathrm{KM}$ 濃度 に中耳炎耳と正常耳との間に有意差を認めなか った。との結果から、中耳炎耳と正常耳におけ る内耳の易傷性の差は, 外リンパへの薬剂移行 の多宣によるためではなくむしろ有毛細胞の感 受性の差に起因するすのと考えられた。しかし， 有毛細胞への到達経路としては内リンパからの あのあ考えられて抢り，今回は内リンパ中の薬 剂濃度の計測は行っていないので，内リンパ中 への移行が増大したという可能性は残されてい る.

$\mathrm{KM}$ を投与しないコントロール群において， 左側の基底回転起始部に中耳炎の内耳波及によ る外有毛細胞障害が認められ，先にも述べたよ うに中耳の炎症が機能的, 形態学的な内耳障害 を引き起こすととは明らかである。アミノ配糖 体薬剤による聴器毒性の発現の機序としては, 現在, 薬剤が活性のまま内耳に移行し，内耳へ の高濃度集積と緩徐な排出によって外リンパに

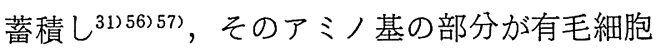
膜に存在する polyphosphoinositide と結合し， 膜機能を障害するためと考えられている ${ }^{58) 59960)}$. 中耳炎により予め障害を受けた有毛細胞が，正 常の状態よりも耳毒性薬剂によってさらに障害 を受けやすいというととは自然な考え方と思わ れる. 中耳炎作成手術21日後に KM 投与を行 った群では，2 日後に KM 投与を行った群に 較べて左側の外有毛細胞障害が高度であった が，乙れは $\mathrm{KM}$ 投与前の炎症の持続期間が長 いため，それだけ内耳への刺激が大きくより障 害されやすい状態にあったためと考えることが できる，また21日群の右側（コントロール側） では，粘膜下結合組織の浮腫や炎症細胞浸潤な どの病理組織学的変化の認められる動物に一致 して有毛細胞障害が認められたが，乙れも同様 に考えることができるであろう。すなわち本実 験の結果加ら，中耳炎耳に打いて正常耳よりあ より高度の障害が認められたのは, 中耳炎耳に 
おいて KM の外リンパへの移行が増大したた めではなく，炎症と耳毒性薬剂という複数の障 害因子が負荷されたととによって有毛細胞の易 傷性が高まり，各々単独による障害よりも相乗 的な障害が引き起こされたためと考えられた。

2 種類以上の聴器障害因子の併用負荷実験之 しては，DKB (3'，4'-dideoxykanamycin B) 投 与モルモットに音響暴露を行い，内耳への傷害

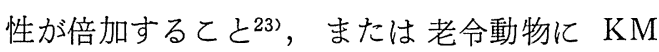
投与を行って電気生理学的, 組織学的に検索を 行い，加令が耳毒性薬剂に対して易傷性が高い という実験的な研究報告 ${ }^{61)}$ が見られる。このよ うに内耳に対しすでにある障害因子が負荷さ れ，有毛細胞が障害されて受傷性が高まってい る条件のもとにさらにもう1つの負荷が加えら れると，障害が相乗的に惹起されるという傾向 があることが他の実験であ証明されている.

3. 臨床使用上の問題点

慢性中耳炎の耳漏細菌の種類について，プロ テウス属, シュードモナス属などのグラム陰性 桿菌の検出率が年次的に高くなっている傾向が あることが明らかにされており ${ }^{62363) ， 乙 れ ら に ~}$ 対し，アミノ配糖体薬剤を使用する機会が増加 するととが予想される，中耳炎耳に扔いて耳毒 性薬剂を使用するにあたり，過去において局 所的に点耳することの危険性は警告されてい る ${ }^{39749)}$. 今回の著者の実験汃ら，耳毒性薬剤を 全身的に投与した場合にあ，中耳炎耳において は高度の内耳障害が惹起される危険性のあるこ とが明らかとなった．とれらの楽剤による内耳 障害は, 一旦惹起されると不可逆性で回復が望 めないため，臨床的に薬剤を使用するにあたっ ては充分な注意が必要である，また中耳炎以外 の他疾患の治療を目的にてれらの薬剂を全身的 に使用する場合，慢性中耳炎の合併の有無を確 認し, 必要に応じて聴力検査を行っておくこと が肝要である。

\section{まとめ}

モルモットに実験的中耳炎を作成し，アミノ 配糖体薬剤 (KM) を全身的に投与して，中耳
炎耳之正常耳の内耳障害について病理組織学 的, 生化学的に比較検討を行い, 次の結果を得 た。

1. 一側の耳管咽頭口を閉鎖することによ り，同側の化膿性中耳炎抢よび漿液性中耳炎の 発症をみた。

2. 実験的中耳炎動物に KM を全身的に投 与した結果，中耳炎耳に扔いては正常耳におい てよりも有意に高度な外有毛細胞障害が認めら れた。

3. 薬剂の外リンパ中濃度は中耳炎耳と正常 耳との間に有意差が認められず，中耳炎耳にお いて障害が増強されたのは，薬剤の外リンパへ の移行が増大したためではなく，炎症と耳毒性 薬剤という複数の障害因子が負荷されたととに よって, 有毛細胞の易傷性が高まり, 各々単独 による障害よりも相乗的な障害が引き起てされ たためと考えられた。

4. 中耳炎耳に扔いてはアミノ配糖体薬剂を 全身的に投与した場合に，高度の内耳障害が惹 起される危険性があるため, 臨床的使用する にあたっては充分な注意が必要と考えられた。

稿を終わるにあたり，終始御懇篤なる御指導と御校 閲を賜わりました恩師大谷 㦑教授に深く感謝致しま す．また協力を惜しまれなかった当教室の諸先生，諸 氏, 側頭骨病理標本作成に御協力頂いた佐藤悦子医療 技師に感謝の意を表します。

なお本論文の要旨は，第35回日本基礎耳科学会，第 89回日本耳鼻咽喉科学会総会, 第37回東北連合学会に おいて発表した.

\section{参考文献}

1) Schuknecht HF : Techniques for study of cochlear function and pathology in experimental animals. Developement of the anatomical frequency scale for the cat. Arch Otolaryngol 58 : 377 397, 1953.

2 ）堀川基治 : Graphic Cochlear Reconstruction 法 とてれによる Acoustic Trauma の研究. 日大医 誌 19 :2728〜2737, 1960.

3) Ohtani I, Mizuno S, Mafune N, et al : Exper imental study on kanamycin concentration in 
blood, cerebrospinal fluid and perilymph in rabbits. Fukushima J Med Sci 22 : 11 18, 1976.

4) Proud GO and Odoi $\mathrm{H}:$ Effect of eustachian tube ligation. Ann Otol Rhinol Laryngol 79 : 30 32, 1970.

5 ) Tos M, Wiederhold M and Larsen P : Experimental long-term tubal occulsion in cat. A quantitative histopathological study. Acta Otolaryngol $97: 580 \sim 592,1984$.

6 ) Sade J, Carr CD and Senturia BH : Middle ear effusions produced experimentally in dogs. Ann Otol Rhinol Laryngol 68 : 1017 1027, 1959.

7) Senturia BH, Carr CD and Ahlvin RC : Middle ear effusions. Pathologic changes of the mucoperiostium in the experimental animal. Ann Otol Rhinol Laryngol $71: 632 \sim 647,1962$.

8 ) 深谷 卓, 野村恭也 : 滲出性中耳炎モルモットに おける蝸牛空膜損傷. 耳鼻 $26: 863 \sim 865,1982$.

9 ) Reiner CE and Pulec JL : Experimental production of serous otitis media. Ann Otol Rhinol Laryngol $78: 880 \sim 888,1982$.

10) Sala $O$ and DeStefani G : Modification caused by the occulsion of the tube on the mucosa of the middle ear. Laryngoscope $73: 320 \sim 329,1963$.

11）平出文久：実験的滲出性中耳炎の病態についての 研究. 日耳鼻 $77: 907 \sim 916,1974$.

12）原田勇彦, 川端五十鈴, 野村恭也：蝸牛空膜の透 過性に関する実験的研究. 耳鼻 $28: 857 \sim 862$, 1982.

13) Senturia BH, Carr $\mathrm{CD}$ and Rosenblüt B : Middle ear effusions produced experimentally in dogs III. Further studies concerning the pathogenesis of the effusions. Acta Otolaryngol 54 : 383 392, 1962.

14）寺本典代：モルモット耳管咽頭口への電子線照射 による実験的滲出性中耳炎 (第 2 報). 耳展 28 : 573 579, 1985.

15）国分典代，天津睦郎：モルモット耳管咽頭口への 電子線照射による実験的滲出性中耳炎 (第 1 報). 耳展 $27: 139 \sim 146,1984$.

16）真崎正美：実験的滲出性中耳炎における鼓膜の形 態的変化一緊張部を中心に一. 耳展 補 2 : 109 127, 1985.

17）後藤修二：慢性中耳炎之内耳障害. 耳喉 $42: 657$
〜61, 1970.

18）中井義明，金子 実：慢性中耳炎における感音性 難聴. 耳喉 $47: 61 \sim 69,1975$.

19）小針仁美，大谷 巌，赤池幑哉，他：慢性中耳炎 における骨導聴力低下について。臨床耳科 11 : 254 255, 1984.

20) Paparella MM, Morizono T, Le CT, et al : Sensorineural hearing loss in otitis media. Ann Otol Rhinol Laryngol 93 : 623 629, 1984.

21) Walby AP, Barrera A and Schuknecht HF : Cochlear pathology in chronic suppurative otitis media. Ann Otol Rhinol Laryngol 92 Suppl $103: 3 \sim 19,1983$.

22）中井義明：ヒトおよび動物中耳病変の内耳への波 及に関する形態的研究. 耳鼻臨床 $67: 1199$ 1201, 1974.

23）中井義明：内耳性難聴一原因, 病態および治療へ のアプローチー. 295〜299頁, 医学教育出版社, 東京, 1985.

24) Papallera MM, Oda M, Hiraide F, et al : Pathology of sensorineural hearing loss in otitis media. Ann Otol Rhinol Laryngol 81 : 632 647, 1972.

25) Papallela MM and Sugiura $S$ : The pathology of suppurative labyrinthitis. Ann Otol Rhinol Laryngol $76: 554 \sim 586,1967$.

26) Hodges KB, Penny JE, Brown RD, et al : Scanning electron microscopy of the cochlea in rats with Streptococcus pneumoniae otitis media. Arch Otolaryngol $110: 429 \sim 436,1984$.

27）鈴木康之：鼓室の急性炎症における内耳液の免疫 学的研究. 一第 2 編 鼓室の急性炎症に対する内 耳液蛋白の変動について一. 日耳鼻 $80: 732 \sim$ 742, 1977.

28) Federspil P : Ototoxicität der AminoglykosideAntibiotica und Otitis media. Arch Ohr Nas Kehlkopfheilk 207 : 487 488, 1974.

29）加藤隆一：臨床薬理学領域における pharmacokinetics. 臨床薬理 $9: 107 \sim 110,1978$.

30）中島礼士, 渡部泰夫, 小田隆造, 他: カナマイシ ンの内耳液移行に関する実験的研究. 日耳鼻 $72: 748 \sim 751,1969$.

31) 橘 正芳 : 臟器内濃度および排出能からみたカナ マイシンの難聴の発現機序. 日耳鼻 $80: 40 〜 54$, 1975. 
32）橘 正芳 : Freeze-fracture 法・組織化学法による 蝸牛の電顕的観察一アミノ配糖体抗生物質による 聴器障害理解のために一. 日耳鼻 $80: 156 〜 166$, 1977.

33）小出 靖: カナマイシン感受性の諸問題. 耳鼻臨 床 $60: 95 \sim 109,1967$.

34) Saito $H$ and Daily JF : Quantitative analysis of acid mucopolysaccharides in the normal and kanamycin intoxicated cochlea. Acta Otolaryngol $71: 22 \sim 26,1971$.

35) Lawrence $M$ : Effect of interference with terminal blood supply on organ of Corti. Laryngoscope $76:$ 1318 1337, 1966.

36) Parrisch KL, Tachibana M, Domer FR, et al : Ototoxicity of intracisternal gentamicin in cats. Ann Otol Rhinol Laryngol 90 : 255 260, 1981.

37）秦 篤夫：カナマイシン難聴における正円空膜透 過性の意義. 耳鼻臨床 $60: 429 \sim 436 ， 1967$.

38）飯島宗一, 影山圭三, 石川栄世, 他 : 組織病理了 トラス. 16〜20頁, 文光堂, 東京, 1984 .

39）野村恭也：点耳療法による内耳障害について. 耳 喉 $51: 857 \sim 862,1979$.

40）富山道夫, 田中久夫, 今井昭雄, 他 : Cefamandole の滲出性中耳炎貯留液中への移行について. 耳鼻 33 : 366～369， 1987.

41) Krauze PJ : Penetration of Amoxicillin, Cefaclor, Erythromycin-Sulfisoxazole and TrimethoprimSulfamethoxazole into the middle ear fluid of patient with chronic serous otitis media. J Infec Dis $145: 815 \sim 821,1981$.

42) Edén $T$ : Long-standing otitis media with effusion-a convenient model for the study of antibiotic penetration to respiratory tract secretions-. Scand J Infect Dis 44 Suppl : 46 51, 1985.

43) Schuknecht HF : Ablation therapy for the relief of Menieres disease. Laryngoscope 66:859 870, 1956.

44) Koide Y, Hata A and Hando R : Vulnerability of the organ of corti in poisoning. Acta Otolaryngol $61: 332 \sim 344,1966$.

45）豊田弥八郎：アミノ配糖体系抗生物質による内耳 障害様式に関する実験的研究. 耳鼻臨床 $67: 481$ $\sim 494,1974$.

46）中井義明, 山本 䉒，五十嵐真 : 鼓室内薬㶡によ
る内耳障害. Audiology Japan $17:$ 190 197, 1974.

47) Brummett RE, Harris RF and Lindgren JA : Detection of ototoxicity from drugs applied topically to the middle ear space. Laryngoscope 86 : 1177 1187, 1976.

48）野村恭也：蝸牛空. 57〜 97頁，第83回日耳鼻総会 宿題報告, 1982 .

49）野村恭也：点耳薬性難聴について. 耳展 18：541 $\sim 546,1975$.

50) Brady DR, Pearce JP and Juhn SK : Permeability of round window membrane to ${ }^{22} \mathrm{Na}$ or RISA. Arch Otolaryngol $214:$ 183 184, 1976.

51) Smith BM and Meyers MG : The penetration of gentamicin and neomycin into perilymph across the round window membrane. Otolaryngol Head Neck Surg 87 : 888 891, 1979.

52) Harada $T$, Iwamori $M$, nagai $Y$, et al : Ototoxicity of neomycin and its penetration through the round window membrane into the perilymph. Ann Otol Rhinol Laryngol 95 : 404 408, 1986.

53) Goycoolea MV, Paparella MM, Goldberg B, et al : Permeability of the round window membrane in otitis media. Arch Otolaryngol $106: 430 \sim 433$, 1980.

54) Sahni RS, Paparella MM, Schachern PA, et al : Thickness of the human round window membrane in different forms of otitis media. Arch Otolaryngol Head Neck Surg 113:630 634, 1987.

55) Schachern PA, Paparella MM, Goycoolea MV, et al : The permeability of the round window membrane during otitis media. Arch Otolaryngol Head Neck Surg 113 : 625 629, 1987.

56) Stupp, HF : Untersuchung der Antibiotikaspiegel in den Innenohrflüssigkeiten und ihre Bedeutung für die Spezifische Ototoxizität der Aminoglykosidantibiotika. Acta Otolaryngol Suppl 262: 1970.

57) Watanabe Y, Nakajima R, Oda R, et al : Experimental study on the transfar of kanamycin to the inner ear fluids. Med J Osaka Univ 21 : 257 263, 1971.

58) Schacht J : Biochemistry of neomycin ototoxicity. 
J Acoust Soc Am 59 : 940 944, 1976.

59) Schacht J : Isolation of an aminoglycoside receptor from guinea pig inner ear tissues and kidney. Arch Otorhinolaryngol $224: 129 \sim 134,1979$.

60) Stockhorst E and Schacht J : Radioactive labeling of phospholipids and proteins by cochlear perfusion in the guinea pig and the effect of neomycin. Acta Otolaryngol 83 : 401 409, 1970.

61) Henry KR, Chole RA, McGinn MD, et al : Increased ototoxicity in both young and old mice. Arch Otolaryngol $107:$ 92 95, 1981.
62）野中信二, 北 真行, 森弘: 最近経験した慢 性中耳炎200耳の耳漏細菌の動向.耳鼻臨床 76 : 455 461, 1983.

63）山内盛雄, 山本悦生, 生司和彦, 他: 慢性中耳炎 耳漏検出菌之薬剂感受性. 耳鼻臨床 $74: 1385$ 1392, 1981.

$$
\left(\begin{array}{l}
\text { 原稿採択 : 昭和 } 63 \text { 年 } 10 \text { 月 } 28 \text { 日 } \\
\text { 別刷請求先 : 小針仁美 } \\
\text { 个960-12 福島市光が丘 } 1 \text { 番地 } \\
\text { 福島県立医科大学耳鼻咽喉科学教室 }
\end{array}\right)
$$

